\title{
Assessment of Egyptian Maize Hybrids for Their Capability of Plant Regeneration using Immature Embryo Culture
}

\author{
Shaimaa M. Awad-Allah, Yohana Kuku, Sanaa I. Milad, M N Barakat ${ }^{* 1}$
}

\begin{abstract}
The aim of this research was to determine the regeneration capability of five maize hybrids (Syngenta hybrid, Three-way hybrid (324), Single cross hybrid P344 (Pioneer), Single cross hybrid 30N 11 (Pioneer) and Threeway hybrid (321)) using immature embryo explants with four medium protocols. The analysis of variance for in vitro culture traits of explant response indicated that callus induction, callus weight and embryogenic callus significantly responded to maize genotypes, medium protocols and their interaction. Also differences among maize hybrids were highly significant for shoot formation $(\%)$, while they were not significant for root formation $(\%)$. The four medium protocols indicated highly significant differences for root formation $(\%)$ and shoot formation (\%). Three-way hybrid (324) and Single cross hybrid 30 N11(Pioneer) had the highest induction frequency of shoot formation on medium protocol D. Both maize hybrids on medium protocol $D$ could be successfully utilized for the in vitro selection studies for maize improvement.
\end{abstract}

Keywords: Maize, Immature embryo, Tissue culture, Plant regeneration

\section{INTRODUCTION}

In Africa, Maize potential as an export crop is increasing over years, which goes in line with the rapid increase in world population imposing the necessity for more maize food consumption and higher needs for livestock feed requirements. However, current status of maize grain production doesn't meet these increasing demands and puts boosting maize grain yield production as a breeder priority to ensure food security especially in developing countries, In Egypt, the cultivated area with maize reached 2.61 million feddans $(1.1$ million hectares) in 2020, slightly above the 2.56 million feddans (1.07 million hectares) in 2019 (FAO; 2020).

A main part of biotechnology application that mediates crops genetic manipulation and serves in plant breeding is regeneration of plants from cells and plant parts via tissue culture. Haplodization, somaclonal variation, cell suspension culture, protoplasts and DNA delivery techniques remain the key approaches of tissue culture to regenerate plant breeding materials (Barakat and Cocking, 1989, Barakat, 1994, Henry et al., 1994; Barakat, et al 2017). The expected outcomes of these technologies are increased genetic variation in addition to saving time.

The development of cell and tissue culture techniques in cereal crops has received considerable attention in recent years. The successful application of plant biotechnologies to maize improvement is dependent on the development of efficient systems for the regeneration of plants from cultured cell and tissues. Bohorova et al. (1999) opened the discussion about the capacity to produce regenerable callus lines from immature embryos that appear to be genotypedependent in many species, including maize (Dhillon and Gosal 2018, Guruprasad et al. 2018; Pervin et al. 2019).

Improving tolerance to biotic and abiotic stresses through in vitro selection should be preceded by optimizing an efficient in vitro plant regeneration system (Barakat and Abdel-Latif 1996) and genetic transformation (Ishida et al., 1996; Bohorova et al., 1999).

In this study, using immature embryo explants, five maize hybrids were assessed for their shoot formation and subsequently plant regeneration potential on four culture medium protocols. The obtained results of morphogenesis should offer valuable information for further investigations aiming to improve tolerance against abiotic stresses.

\section{MATERIALS AND METHODS}

\section{Plant materials}

Seeds of five Egyptian maize hybrids with different background Syngenta hybrid, three-way cross 324 (T.C. 324), single cross 321 Pioneer (S.C. P344 Pioneer), single cross 30N 11 Pioneer (S.C. 30N 11 Pioneer) and three-way cross 321 (T.C. 321), were obtained from Maize Research Section, Nubaria Research Station, Field Crop Research Institute, Agriculture Research Center, Egypt. The five Egyptian

\footnotetext{
DOI: 10.21608/asejaiqjsae.2021.186822

${ }^{1-}$ Biotechnology Laboratory, Crop Science Department,

Faculty of Agriculture, University of Alexandria,

P.O. Box 21545, Alexandria, Egypt

*E-mail correspondence author: mnrbarakat@yahoo.com

Received June 05, 2021, Accepted, July 29, 2021.
} 
maize hybrids were grown in summer season of 2019 at the Experimental Farm Station, Faculty of Agriculture, Alexandria University, Alexandria, Egypt.

\section{Culture preparation and condition}

Maize kernels were surface sterilized by immersing in ethanol $75 \%$ for one min., then immersing in $0.1 \%$ mercuric chloride with two drops of Tween-20 as a wetting agent for $15 \mathrm{~min}$. and finally washed with six changes of sterile distilled water. Immature embryos (1.5- $2 \mathrm{~mm}$ long) were excised from the seeds under aseptic conditions. The kernels were placed in distilled Petri dish and the tip of kernel was cut off with a sharp scalpel blade without touching the embryo and press using the back of blade to separate the embryo away from the kernel.

Full details of the four medium protocols studied, previously developed and successfully employed by other workers for maize, used for callus induction, differentiation and root formation are given in Table 1.

Table 1. Components of the four medium protocols used for callus induction and plant regeneration in maize.

\begin{tabular}{|c|c|c|c|c|}
\hline \multirow[b]{2}{*}{ Protocol } & \multirow[b]{2}{*}{ Component } & \multicolumn{3}{|c|}{ Medium sequence } \\
\hline & & $\begin{array}{c}\text { Callus } \\
\text { induction }\end{array}$ & $\begin{array}{c}\text { Callus } \\
\text { differentiation }\end{array}$ & $\begin{array}{c}\text { Root } \\
\text { formation }\end{array}$ \\
\hline & & MS (1X) & MS (1X) & MS (1X) \\
\hline & & (salts +vitamins) & (salts +vitamins) & (salts +vitamins) \\
\hline & L-Asparagine & $150.0 \mathrm{mg}$ & - & - \\
\hline A & $2,4-\mathrm{D}$ & $0.5 \mathrm{mg}$ & - & - \\
\hline \multirow[t]{7}{*}{ (Lowe et al., 1985) } & Kinetin & - & $10.0 \mathrm{mg}$ & - \\
\hline & Sucrose & $120 \mathrm{~g}$ & $20 \mathrm{~g}$ & $30 \mathrm{~g}$ \\
\hline & Activated charcool & - & - & $10 \mathrm{~g}$ \\
\hline & Agar & $7.0 \mathrm{~g}$ & $7.0 \mathrm{~g}$ & $7.0 \mathrm{~g}$ \\
\hline & & N6 salts & N6 salts & $\operatorname{MS}(0.5 \mathrm{X})$ \\
\hline & & + B5 vitamins* & + B5 vitamins* & (salts +vitamins) \\
\hline & Glycine & $2.0 \mathrm{mg}$ & $2.0 \mathrm{mg}$ & - \\
\hline $\mathrm{B}$ & L-proline & $690 \mathrm{mg}$ & - & - \\
\hline \multirow[t]{8}{*}{ (Huang and Wei, 2004) } & Casein hydrolysate & $1.0 \mathrm{~g}$ & - & - \\
\hline & $2,4-\mathrm{D}$ & $4 \mathrm{mg}$ & - & - \\
\hline & BAP & - & $0.5 \mathrm{mg}$ & - \\
\hline & IBA & - & - & $0.6 \mathrm{mg}$ \\
\hline & Sucrose & $30 \mathrm{~g}$ & $30 \mathrm{~g}$ & $15 \mathrm{~g}$ \\
\hline & Agar & $8.0 \mathrm{~g}$ & $8.0 \mathrm{~g}$ & $6.0 \mathrm{~g}$ \\
\hline & & N6 salts & MS (1X) & MS (1X) \\
\hline & & +MS vitamins & (salts +vitamins) & (salts +vitamins) \\
\hline $\mathrm{C}$ & & without inositol & & \\
\hline \multirow[t]{8}{*}{ (Bronsema et al., 1997) } & L-proline & $2.3 \mathrm{~g}$ & - & - \\
\hline & Casein hydrolysate & $200 \mathrm{mg}$ & - & - \\
\hline & $2,4-\mathrm{D}$ & $2.0 \mathrm{mg}$ & - & - \\
\hline & Sucrose & $20 \mathrm{~g}$ & $20 \mathrm{~g}$ & $30 \mathrm{~g}$ \\
\hline & Agar & $8.0 \mathrm{~g}$ & $8.0 \mathrm{~g}$ & $8.0 \mathrm{~g}$ \\
\hline & & N6 salts & MS (1X) & MS (1X) \\
\hline & & +MS vitamins & (salts +vitamins) & (salts +vitamins) \\
\hline & & without inositol & & \\
\hline \multirow[t]{7}{*}{ (Armstrong et al., 1991) } & Inositol & - & $900 \mathrm{mg}$ & $400 \mathrm{mg}$ \\
\hline & L-proline & $2.88 \mathrm{~g}$ & - & - \\
\hline & Silver nitrate & $1.7 \mathrm{mg}$ & - & - \\
\hline & $2,4-\mathrm{D}$ & $1.0 \mathrm{mg}$ & - & - \\
\hline & NAA & - & $1.0 \mathrm{mg}$ & - \\
\hline & Sucrose & $20 \mathrm{~g}$ & $30 \mathrm{~g}$ & $30 \mathrm{~g}$ \\
\hline & Agar & $7.0 \mathrm{~g}$ & $7.0 \mathrm{~g}$ & $7.0 \mathrm{~g}$ \\
\hline
\end{tabular}


The $\mathrm{pH}$ of all the media used was adjusted to 5.8, using $1.0 \mathrm{M} \mathrm{HCl}$ or $1.0 \mathrm{M} \mathrm{NaOH}$. The agar was added after adjusting $\mathrm{pH}$. The media were then sterilized by autoclaving at $121^{\circ} \mathrm{C}(108 \mathrm{kPa})$ for $20 \mathrm{~min}$.

\section{Callus induction response:}

For callus induction, the experiments were performed in Petri dishes. Five immature embryos were cultured per $9 \mathrm{~cm}$ Petri dish containing $25 \mathrm{ml}$ of culture medium with the embryo axis in contact with the surface of agar-solidified medium. Each dish was considered as one replicate. Five replicates were used for each genotype per protocol. Cultures were incubated in the dark at $25 \pm 2^{\circ} \mathrm{C}$ for six weeks. After six weeks of incubation, callus induction response was recorded as three variables for each petri dish, (1) the percentage of embryo explants which had callused on the initiation medium (callus formation), (2) the fresh weight $(\mathrm{g})$ of the initiated callus (callus weight) and (3) the percentage of embryogenic callus derived from the embryo explants.

\section{Plant regeneration}

Calli derived from immature embryo explants were transferred to regeneration media sequences (Table 1). The cultures were maintained at $25 \pm 2^{\circ} \mathrm{C}$ under 16 hours of illumination (2,000 lux, day light fluorescent tubes), and after four weeks the percentage of calli with green shoots which exceeded $1 \mathrm{~cm}$ in length (shoot formation) was recorded for each petri dish. Regenerated shoots were transferred to MS medium devoid of growth regulators or MS + IBA (Table 1) for further development. After shoots and roots had developed, regenerated plantlets were washed in tap water to remove agar from the roots and were transplanted into small pots filled with sand: peatmoss (1:1). The pots were incubated under moist conditions for acclimatization and establishment.

\section{Statistical analysis}

Data of in vitro traits were analyzed as a two- factor experiment (Egyptian maize hybrid and medium protocols) using Randomized Complete Block Design (RCBD) with five replicates for callus induction response and with three replicates for morphogenetic response. All data, except the callus weight were subjected to arcsine transformation prior to statistical analysis (Steel and Torrie, 1980). Comparisons among means were made using the Least Significant Differences (LSD). Data were analyzed, using SAS (2002) program.

\section{RESULTS AND DISCUSSION}

\section{In vitro culture traits of explant response to callus induction}

The results of in vitro culture traits of explant response to callus induction could be presented as follows:

\section{Callus induction}

The analysis of variance presented in Table 2 illustrates that callus induction responded significantly to differences in maize genotypes, medium protocols and the interaction between genotypes and medium protocols.

Callus formation varied widely among maize genotypes (Table 3). The percentage of immature embryo explants that developed calli, ranged from $27 \%$ (Syngenta hybrid) to 55\% (single cross hybrid $30 \mathrm{~N} 11$ "Pioneer"), for all genotypes across the four medium protocols with an average of 39\% (Table 3).

The response of callus induction varied according to its medium (Table 3) where the medium protocol D gave the highest average of callus induction (56.8\%) across genotypes. However, it was not significantly different from medium B (52\%) and medium C $(47.2 \%)$, while, medium protocol A not give any response for callus induction $\%$ across all the studied genotypes (Table 3).

Interaction between genotypes and medium protocols was highly significant for callus induction $\%$ (Table 2). The medium protocols B and $\mathrm{C}$ produced the highest callus induction $(80 \%)$ and $(88 \%)$, respectively, from S.C. $30 \mathrm{~N} 11$ (Pioneer) and medium protocol B from T.C.324(76\%) as shown in (Table 3).

\section{Callus weight}

The analysis of variance presented in Table 2 indicated that callus weight ( $\mathrm{g} / 5$ immature explants) was significantly influenced by differences in maize genotypes, medium protocols and the interaction between genotypes and medium protocols.

Data presented in table 4 indicated that callus weight varied widely among maize genotypes, where weight of callus ranged from 0.229 (g) for S.C. P344 (Pioneer) to $0.481(\mathrm{~g})$ for (Syngenta hybrid) that wasn't significantly equaled with(T.C. 324) $0.479(\mathrm{~g})$ for all genotypes across the four medium protocols with an average of $0.359(\mathrm{~g})$.

Among medium protocols, D gave the highest callus weight $(0.561 \mathrm{~g} / 5$ explants $)$, which was significantly different from A and C medium protocols (Table 4). 


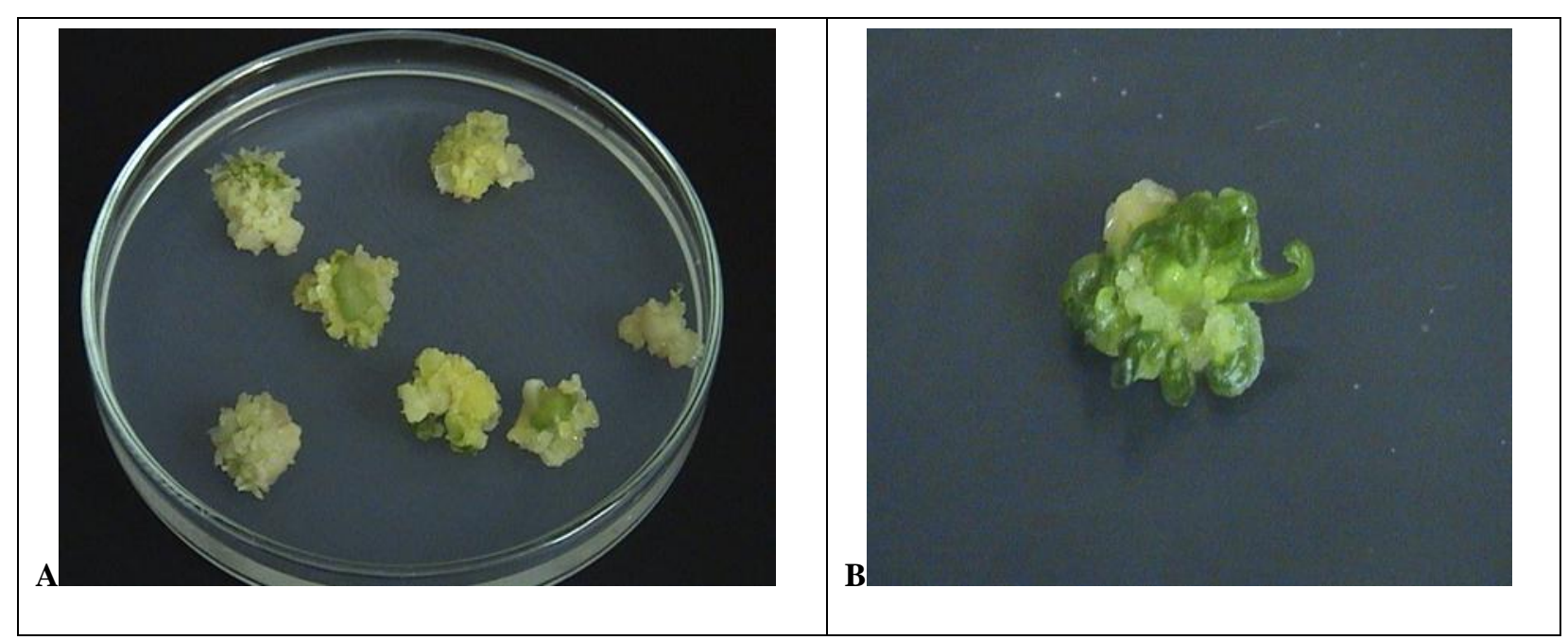

Fig.1. Callus formation after six weeks (A) and masses of green nodules in culture germinate into leaf- like structures (B).

Table 2. Mean squares of the analyses of variance for in vitro traits culture in maize.

\begin{tabular}{|c|c|c|c|c|c|c|c|}
\hline \multirow[t]{2}{*}{$\begin{array}{ll}\text { Source of } \\
\text { Variance }\end{array}$} & \multirow[t]{2}{*}{ D.F. } & \multicolumn{3}{|c|}{$\begin{array}{l}\text { M.S. for in vitro culture traits of } \\
\text { explant response to callus induction }\end{array}$} & \multirow[t]{2}{*}{ D.F. } & \multicolumn{2}{|c|}{$\begin{array}{l}\text { M.S. for in vitro culture traits of } \\
\text { morphogenetic response }\end{array}$} \\
\hline & & $\begin{array}{c}\text { Callus } \\
\text { Induction } \\
(\%)\end{array}$ & $\begin{array}{c}\text { Callus } \\
\text { Weight } \\
(\mathrm{g})\end{array}$ & $\begin{array}{c}\text { Embryogeni } \\
\text { c } \\
\text { Callus } \\
(\%)\end{array}$ & & $\begin{array}{c}\text { Root } \\
\text { Formation } \\
(\%)\end{array}$ & $\begin{array}{c}\text { Shoot } \\
\text { Formation } \\
(\%)\end{array}$ \\
\hline Replicates & 4 & 145.8 & 0.069 & 167.7 & 2 & 124.01 & 64.3 \\
\hline Genotypes (A) & 4 & $1759.6^{* *}$ & $0.0262 * *$ & $2235.3 * *$ & 4 & $249.6^{\mathrm{ns}}$ & $500.4 * *$ \\
\hline Protocols (B) & 3 & $13082.1 * *$ & $1.552 * *$ & $6256.4 * *$ & 3 & $4677.6^{* *}$ & $1616.4^{* *}$ \\
\hline A X B & 12 & $1624.5^{* *}$ & $0.142 * *$ & $1581.6^{* *}$ & 12 & $401.9 * *$ & $135.6^{\mathrm{ns}}$ \\
\hline Error & 76 & 205.6 & 0.024 & 169.8 & 38 & 110.7 & 104.2 \\
\hline
\end{tabular}

** significant at 0.01 level of probability.

n.s.; not significant.

Table 3. Means of callus induction (\%) as influenced by genotypes, media and their interaction.

\begin{tabular}{|c|c|c|c|c|c|}
\hline \multicolumn{6}{|c|}{ Protocols } \\
\hline Hybrids & $\mathbf{A}$ & $\mathbf{B}$ & $\mathbf{C}$ & D & Mean \\
\hline Syngenta hybrid & $0.00^{\mathrm{d}}$ & $20^{\mathrm{c}}$ & $28^{\mathrm{c}}$ & $60^{\mathrm{b}}$ & $27^{\mathrm{c}}$ \\
\hline Three-way hybrid (324) & $0.00^{\mathrm{d}}$ & $76^{\mathrm{ab}}$ & $52^{\mathrm{b}}$ & $68^{\mathrm{b}}$ & $49^{\mathrm{ab}}$ \\
\hline Single cross hybrid P 344 (pioneer) & $0.00^{\mathrm{d}}$ & $28^{\mathrm{c}}$ & $68^{\mathrm{b}}$ & $36^{\mathrm{c}}$ & $33^{\mathrm{bc}}$ \\
\hline Single cross hybrid $30 \mathrm{~N} 11$ (Pioneer) & $0.00^{\mathrm{d}}$ & $80^{\mathrm{ab}}$ & $88^{\mathrm{a}}$ & $52^{\mathrm{b}}$ & $55^{\mathrm{a}}$ \\
\hline Three-way hybrid (321) & $0.00^{\mathrm{d}}$ & $56^{\mathrm{b}}$ & $0.00^{\mathrm{d}}$ & $68^{\mathrm{b}}$ & $31^{\mathrm{bc}}$ \\
\hline Mean & $0.00^{\mathrm{b}}$ & $52^{\mathrm{a}}$ & $47.2^{\mathrm{a}}$ & $56.8^{\mathrm{a}}$ & 39 \\
\hline
\end{tabular}

L.S.D. (0.05) for genotype means $=11.27$

L.S.D. (0.05) for medium protocol means $=10.08$

L.S.D. (0.05) for genotype $\mathrm{x}$ medium protocol interaction $=18$ 
Table 4. Means of callus weight (g/ 5 immature explant) as influenced by genotypes, media and their interaction.

\begin{tabular}{lccccc}
\hline & Protocols & & & & \\
Hybrids & A & B & C & D & Mean \\
\hline Syngenta hybrid & 0.00 & 0.501 & $0.80^{\mathrm{a}}$ & $0.626^{\mathrm{b}}$ & $0.481^{\mathrm{a}}$ \\
Three-way hybrid (324) & 0.00 & $0.718^{\mathrm{a}}$ & 0.446 & $0.718^{\mathrm{a}}$ & $0.470^{\mathrm{a}}$ \\
Single cross hybrid P 344 (pioneer) & 0.00 & 0.265 & 0.370 & 0.281 & $0.229^{\mathrm{c}}$ \\
Single cross hybrid 30 N 11 (Pioneer) & 0.00 & 0.501 & 0.390 & $0.515^{\mathrm{b}}$ & $0.351^{\mathrm{b}}$ \\
Three-way hybrid (321) & 0.00 & 0.412 & 0.00 & $0.666^{\mathrm{b}}$ & $0.268^{\mathrm{bc}}$ \\
Mean & $0.00^{\mathrm{c}}$ & $0.479^{\mathrm{ab}}$ & $0.401^{\mathrm{b}}$ & $0.561^{\mathrm{a}}$ & 0.359 \\
\hline
\end{tabular}

L.S.D. (0.05) for genotype means $=0.098$

L.S.D. (0.05) for medium protocol means $=0.088$

L.S.D. (0.05) for genotype $\mathrm{x}$ medium protocol interaction $=0.19$

Syngenta hybrid gave the highest callus weight $(0.80 \mathrm{~g} /$ 5 explants) on medium $\mathrm{C}$ and the three-way hybrid 324 gave a high callus weight $0.718(\mathrm{~g})$ on both $\mathrm{B}$ and $\mathrm{D}$ medium protocols (Table 4).

\section{Embryogenic callus}

The analysis of variance of embryogenic callus (\%) revealed highly significant differences among maize genotypes, medium protocols and their interaction (Table 2). The highest percentage of embryogenic callus across the four media was obtained from S.C 30 N11 Pioneer $(46 \%)$ which was significantly higher than the other hybrids (Table 5). The medium protocol $\mathrm{B}$ gave the highest percentage of embryogenic callus (36\%) across genotypes which was not significantly differed from B and C medium protocols (Table 5, Fig.1).

The interaction between genotypes and medium protocols for embryogenic callus was highly significant (Table 2). S.C $30 \mathrm{~N} 11$ (Pioneer) gave the highest percentage of embryogenic callus $(88 \%)$ on medium protocol $\mathrm{C}$, however it dropped to $(0 \%)$ with medium protocol A (Table 5).

\section{Morphogenetic response}

The analysis of variance presented in Table 2 showed that differences among maize hybrids were highly significant for shoot formation (\%) and not significant for root formation (\%), while the four medium protocols indicated highly significant differences for root formation (\%) and shoot formation $(\%)$. The interaction between maize hybrids and the four medium protocols was highly significant for root formation (\%) only.

Medium protocol $\mathrm{D}$ gave the highest and significant value for root formation (44\%) and medium protocol A gave the lowest value of root formation across all the genotypes as compared to the other three media (Table 6, Fig. 2). Concerning the interaction between genotypes and medium protocols, Syngenta hybrid and S.C. 30 N11 (Pioneer) gave the highest percentage of root formation $(60 \%)$ on $\mathrm{D}$ and $\mathrm{C}$ media, respectively. However, they dropped to $0.00 \%$ on medium A (Table $6)$.

Table 5. Means of embryogenic callus (\%) as influenced by genotypes, media and their interaction.

\begin{tabular}{lccccc}
\hline & Protocols & & & & \\
Hybrids & A & B & C & D & Mean \\
\hline Syngenta hybrid & 0.00 & 12 & 16 & 32 & $15^{\mathrm{c}}$ \\
Three-way hybrid (324) & 0.00 & $44^{\mathrm{b}}$ & 20 & $48^{\mathrm{b}}$ & $28^{\mathrm{b}}$ \\
Single cross hybrid P 344 (pioneer) & 0.00 & 24 & $48^{\mathrm{b}}$ & 0.00 & $18^{\mathrm{c}}$ \\
Single cross hybrid 30 N 11 (Pioneer) & 0.00 & $48^{\mathrm{b}}$ & $88^{\mathrm{a}}$ & $48^{\mathrm{b}}$ & $46^{\mathrm{a}}$ \\
Three-way hybrid (321) & 0.00 & $52^{\mathrm{b}}$ & 0.00 & 12 & $16^{\mathrm{c}}$ \\
Mean & $0.00^{\mathrm{b}}$ & $36^{\mathrm{a}}$ & $34.4^{\mathrm{a}}$ & $28^{\mathrm{a}}$ & 24.6 \\
\hline
\end{tabular}

L.S.D. (0.05) for genotype means $=9.87$

L.S.D. (0.05) for medium protocol means $=8.83$

L.S.D. (0.05) for genotype $\mathrm{x}$ medium protocol interaction $=16.4$ 


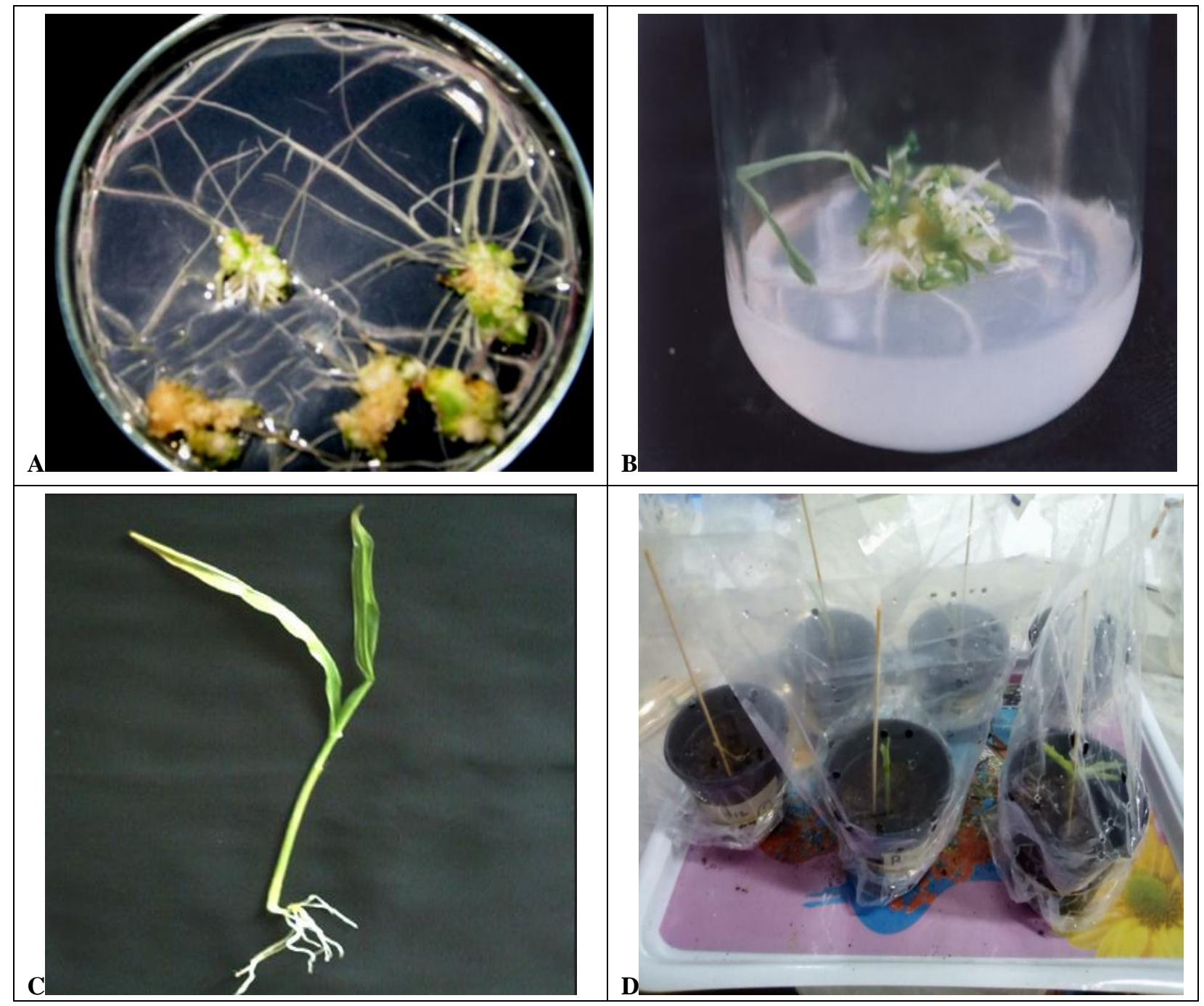

Fig. 2. Morphogenetic response derived immature embryos calli; (A) Root formation, (B) Shoot formation, (C) Plantlet rooted on MS0 medium and (D) Regenerated plants established under greenhouse conditions.

Table 6. Means of root formation (\%) as influenced by genotypes, media and their interaction.

\begin{tabular}{lccccc}
\hline Hybrids & Medium Protocols & & & & \\
S & A & B & D & Mean \\
\hline Syngenta hybrid & 0.00 & 26.67 & 13.3 & $60^{\mathrm{a}}$ & 25 \\
\hline Three-way hybrid (324) & 0.00 & 26.67 & 26.7 & 40 & 23.3 \\
\hline Single cross hybrid P 344 (Pioneer) & 0.00 & 20 & 46.67 & 40 & 26.7 \\
\hline Single cross hybrid 30 N11(Pioneer) & 0.00 & 40 & $60^{\mathrm{a}}$ & 33.3 & 33.3 \\
\hline Three-way hybrid (321) & 0.00 & 33.3 & 0.00 & 46.67 & 20.0 \\
\hline Mean & $0.00^{\mathrm{c}}$ & $29.3^{\mathrm{b}}$ & $29.3^{\mathrm{b}}$ & $44.0^{\mathrm{a}}$ & 25.7 \\
\hline
\end{tabular}

L.S.D. (0.05) for genotype means= NS

L.S.D. (0.05) for medium protocol means $=10.15$

L.S.D. (0.05) for genotype $\mathrm{x}$ medium protocol interaction $=22.7$ 
Results presented in Table 7 showed that the T.C. 324 and S.C. 30 N11 (Pioneer) gave the highest means of shoot formation ( $20 \%$ and $16.7 \%$, respectively) across medium protocols. Medium D showed the highest potential for shoot formation (21.3\%) from other medium protocols (Table 7, Fig. 2) without significant differences with $\mathrm{B}$ and $\mathrm{C}$ media.

A prerequisite for in vitro selection experiments is establishing a robust in vitro plant regeneration system. For a plant that shows no potential for in vitro regeneration, regeneration from variant cell is unlikely to be successful. Once a reliable tissue culture protocol is validated, it is ready to be deployed in in vitro selection studies (Barakat and Abdel-Latif 1996; Barakat and El-Sammak, 2011). This work aimed to establish a tissue culture protocol capable of regenerating plants from a cultured tissue of maize.

Based on the findings of this study, it can be proposed that, the use of tissue culture technique as an aid tool in improving crops, it was necessary to assess the factors affecting callus formation. Its quality and quantity during induction and maintenance and, subsequently, shoot regeneration from callus. The same finding was obtained by Abdel-Latif et al. (2002), and Abdallah et al. (2012), who reported that the callus initiation and its growth rate were dependent upon the genotype and culture medium employed.

Immature embryos were used as the explant in this study, where the totipotency of immature embryo explants of maize has been studied by many workers (Rosati et al., 1994; Abdel-Latif et al. 2002; Malini et al. 2015). They reported that immature embryos of maize can form an embryogenic callus in a reproducible way and with quite high induction frequencies and multiple plantlets can be easily obtained from this embryogenic callus. Some investigators also reported that embryogenic callus derived from immature embryos has the potential to produce multiple plantlets even when prolonged in subculture (Dhillon and Gosal 2018; Guruprasad et al 2018). Pervin et al (2019) reported that the immature embryo explants were good sources for embryogenic callus in their studies. In addition, the manipulation of immature embryos was relatively simple and the risk of contamination was much less than mature embryos.

This study provides an indication of the relative importance of genotype, medium protocol and their interactions effect in culture response. The highly significant differences among genotypes in the studied in vitro traits were in agreement with the previous studies (Abdel-Latif et al., 2002; Danson et al., 2006). They observed a considerable amount of genetic variation for embryogenic callus. The efficiency of callus induction, callus weight and regeneration have been reported to be in part genotype dependent (Milad et al., 2001 and Abdel-Latif et al., 2002). They compared the influence of plant genotype and media modifications on culture behavior and suggested that identification of lines capable of complete differentiation could be realized if the inbred lines should be screened for callus initiation and plant regeneration under several protocols. Rakshit et al. (2010) reported that significant genotypic differences were recorded among the inbred lines in callus induction.

Results of the present study revealed that there was a genotype $\mathrm{x}$ medium interaction for morphogenetic response. The probable reasons of differences in morphogenetic response of in vitro might be attributed either to: (a) genetic differences among the genotypes used, (b) differences in the growth regulators or (c) differences in the growth conditions and age of the source of explants.

Table 7. Means of shoot formation (\%) as influenced by genotypes, media and their interaction.

\begin{tabular}{lccccc}
\hline \multicolumn{1}{c}{ Medium Protocols } & & & & & \\
Hybrids & A & B & C & D & Mean \\
\hline Syngenta hybrid & 0.00 & 6.67 & 6.67 & 13.3 & $6.7^{\mathrm{b}}$ \\
Three-way hybrid (324) & 0.00 & 26.67 & 20.0 & 33.3 & $20^{\mathrm{a}}$ \\
Single cross hybrid P344 (Pioneer) & 0.00 & 6.67 & 13.3 & 13.3 & $8.3^{\mathrm{b}}$ \\
Single cross hybrid 30 N11(Pioneer) & 0.00 & 13.3 & 26.67 & 26.67 & $16.7^{\mathrm{ab}}$ \\
Three-way hybrid (321) & 0.00 & 13.3 & 0.00 & 20.0 & $8.3^{\mathrm{b}}$ \\
Mean & $0.00^{\mathrm{b}}$ & $13.3^{\mathrm{a}}$ & $13.3^{\mathrm{a}}$ & $21.3^{\mathrm{a}}$ & 12 \\
\hline
\end{tabular}

L.S.D. (0.05) for genotype means $=8.43$

L.S.D. (0.05) for medium protocol means $=7.5$

L.S.D. (0.05) for genotype $\mathrm{x}$ medium protocol interaction $=\mathrm{NS}$ 
The influence of the above-mentioned factors on the morphogenetic potential of explant was well documented in the literature (Lu et al., 1983; Tomes and Smith, 1985; Hodges et al., 1986; Zhang et al., 2004; Rafiq et al., 2005). Lu et al. (1983) recorded variations among several commercial maize hybrids. Tomes and Smith (1985) reported that parental genotype is very important in the ability to identify and isolate embryogenic callus after 14 and 28 days in culture. They also reported that the potential number of plantlets per unit callus differed among genotypes. The varying levels of regeneration of genotype in different media indicated that somatic embryogenesis and regeneration in maize was genotype specific and the expression of the gene for regeneration ability is dependent upon media environment (Hodges et al., 1986; Abdel-Latif et al. 2002; Rafiq et al., 2005)

In summary, this study proposed that before the use of tissue culture technique as an aid tool in improving crops, the importance to determine factors affecting callus formation, its quality and quantity during induction and maintenance and, subsequently, shoot regeneration from callus would be exist. The hybrid maize; Three-way hybrid (324) and Single cross hybrid $30 \mathrm{~N} 11$ (Pioneer) maize had the highest induction frequency of shoot formation on medium protocol D. The two hybrids on medium protocol $\mathrm{D}$ could be successfully utilized for the in vitro selection studies for maize improvement.

\section{REFERENCES}

Abdallah, H. A. L., A. E. Said and M. M. M. Khalafalla. 2012. Establishment of an efficient callus induction and plant regeneration system in some wheat (Triticum aestivum L.) cultivars grown in Sudan. Afric. J. Biotech., 11(16):37933799 .

Abdel-Latif, K. F., M. N. Barakat and M. M. El-Rouby. 2002. Effect of genotype and media on formation of embryogenic callus and plant regeneration in maize. Alex. J. Agric. Res., 47: 19-29.

Armstrong, C. L., C. E. Green and R. L. Phillips. 1991. Development and availability of germplasm with high type II culture formation response. Maize Genet. Coop. Newslet, 65:92-93.

Barakat, M.N. 1994. Combining abilities of in vitro traits in wheat (Triticum aestivum L.) immature embryo cultures. Euphytica76: 169 -175.

Barakat, M.N., A.A. Al-Doss, A.I. Ghazy, K.A. Moustafa, A.A. Elshafei and E.I. Ahmed. 2017. Doubled haploid wheat lines with high molecular weight glutenin alleles derived from microspore cultures. New Zealand Journal of Crop and Horticultural Science. 46: (3) 198-211.

Barakat, M.N. and T.H. Abdel-Latif 1996. In vitro selection of wheat callus tolerant to high levels of salt and plant regeneration. Euphytica, 91:127-140.
Barakat, M N.and E.C. Cocking, 1989. Regeneration of plants from Linum Protoplasts. Biotechnology in Agriculture and Forestry, Vol. 8 (Protoplast and Genetic Engineering 1). P. 160-170.

Barakat, M.N. and H. El-Sammak. 2011. In vitro culture and plant regeneration from shoot tip and lateral bud explants of Gypsophila paniculata L. Journal of Medicinal Plants Research Vol. 5(15), pp. 3351-3358.

Bohorova, N., W. Zhang, P. Julstrum, S. McLean, B. Luna, R.M. Brito, L. Diaz, M.E. Ramos, P. Estanol, M. Pacheco, M. Salgado and D. Hoisington, 1999. Production of transgenic tropical maize with cryIAb and cryIAc genes via microprojectile bombardment of immature embryos. Theor. Appl. Genet., 99: 437-444

Bronsema, F. B. F., W. J. F. Van Oostveen, and A. A. M. Van Lammeren. 1997. Comparative analysis of callus formation and regeneration on cultured immature embryos of the inbred lines A188 and A632. Plant Cell Tissue Organ Culture, 50: 57-65.

Danson, J. W., M. Lagat and M. Mbogori. 2006. Screening tropical maize lines for the production and regeneration of friable and embryogenic type II callus. African J. Biotechnology, 5: 2367-2370.

Dhillon and Gosal .2018. In vitro regeneration by somatic embryos of maize inbreds using mature seeds. Int.J.Curr.Microbiol.App.Sci., 7(11): 725-733.

FAO,2020. Food and Agriculture Organization of the United Nations. 2020. GIEWS Country Brief Egypt global information and early warning system on food and agriculture Reference Date: 30-October-2020

Guruprasad M, V. Sridevi, G.Vijayakumar and M. Satish Kumar. 2018; Plant regeneration through callus initiation from mature and immature embryos of maize (Zea mays L.). Indian J. Agric. Res., DOI:10.18805/ijare.v0iOF.8435

Henry, Y.; P.Vain, and J. De Buyser. 1994. Genetic analysis of in vitro plant tissue culture responses and regeneration capacities. Euphytica, 79:45-58.

Hodges, T. K., K. K. Kamo, C. W. Imbrie and M. R. Becwar. 1986. Genotypic specificity of somatic embryogenesis and regeneration in maize. Biotechnology, 4: 219-223.

Huang, X. Q. and Z. M. Wei. 2004. High-frequency plant regeneration through callus initiation from mature embryos of maize (Zea mays L.) Plant Cell Rep., 22: 793800.

Ishida, Y., H. Saito, S. Ohta, Y. Hiei, T. Komari and Kumashiro, 1996. High efficiency transformation of maize (Zea mays L.) mediated by Agrobacterium tumefaciens. Nat. Biotechnol., 14: 745-750

Lowe, K., D. B. Taylor, P. Ryan and K. E. Paterson. 1985. Plant regeneration via organogenesis and embryogenesis in the maize inbred line B73. Plant Sci., 41: 125-132.

Lu, C., V. Vasil and I. K. Vasil. 1983. Improved efficiency of somatic embryogenesis and plant regeneration in tissue cultures of maize (Zea mays L.). Theor. Appl. Genet., 66: 285-289. 
Malini N., C. R. Ananadakumar and S. Hari Ramakrishnan. 2015. Regeneration of Indian maize genotypes (Zea mays L.) from immature embryo culture through callus induction. Journal of Applied and Natural Science, 7 (1): $131-137$.

Milad, S.I, M.I. Motawei, M.N. Barakat, M.A. Moustafa and Y.H. El-Daoudi. 2001. Genotype and media effects on somatic embryogenesis and shoot formation in some Egyptian wheat cultivars (Triticum spp.). Alex. J. Agric. Res., 46: 37-46

Pervin M.M., M.d. Abul Kalam Azad, M.d. Arifuzzaman, M.d. Ashiqur Rahman, Shahriar Rahman Shovon and M.d. Kaisar Ali .2019. Regeneration of plant through embryo culture from promising maize (Zea mays $L$.) inbred lines. Acta Scientific Agriculture 3(11): 55-61.

Rafiq, M., T. Fatima, T. Husnain, K. Bashir and S. Riazuddin. 2005. Effect of different media on callus formation and regeneration of different genotypes of maize (Zea mays L.). Plant Tissue Cult., 15: 57-65.

Rakshit, S., Z. Rashid, J.C. Sekhar, T. Fatima and S. Dass, 2010. Callus induction and whole plant regeneration in elite Indian maize (Zea mays L.) inbreds. Plant Cell Tissue Org. Cult.,100: 31-37

Rosati, C., P. Landi and R. Tuberosa. 1994. Recurrent selection for regeneration capacity from immature embryo-derived calli in maize. Crop Sci., 34: 343-347.

SAS Institute Inc. (2002) SAS/STAT. Guide for personal computers. Version 8, 1edn. SAS end. SAS institute, Cary. N. C., USA.

Steel, R.G. D. and J.H. Torrie. 1980. Principles and Procedures of Statistics: A Biometrical Approach. McGraw-Hill Book Company, NY. USA. pp.633

Tomes, D.T. and O. S. Smith. 1985. The effect of parental genotype on initiation of embryogenic callus from elite maize (Zea mays L.) germplasm. Theor. Appl. Genet., 70:505-509.

Zhang, H.W., Z. B. Tan, G. Chen and J. S. Li. 2004. Evaluation of elite inbred lines of maize (Zea mays L.) group tangsipingtou for in vitro culture and plant regeneration. Maydica, 49: 273-278.

\section{الملخص العزبي}

\section{تقييم هجن الذرة الثامية المصرية لقدتها على إنتاج نباتات بإستخدام مزارع الأجنة غير الناضجة}

$$
\text { شيماء محمود عوض الله، يوحنا كوكو ، سناء إبراهيم ميلاد ومحمد نجيب بركات }
$$

التباين للإستجابة لصفات التشكل الوراتى أن الاختلافات مابين هجن الذرة الثاميه كانت عالية المعنوية للنسبة المئويه لتشكل المجموع الخضرى، بينما لم تصل هذه الإختلافات إلى مستوى المعنويه لصفة النسبة المئويه لتشكل الجذور • من جهة أخرى فقد سجلت إختلافات عاليه المعنويه مابين البيئات الإربع لصفتى النسبة المئويه لنتكل المجموع الخضرى وتشكل الجذور • وقد أظهر كلاً من الهجينين (هجين ثلاتى ع ب وهجين فردى (30N11 (Pioneer) أعلى نسبة لنتكل المجموع الخضرى على البيئة D. مما يشير إلى نجاح هذيين الهجينين من الذرة الثاميه معمليا باستخدام البيئة لـ.
تهدف هذه الدراسه الى تقييم أربع بيئات غذائية فى قدرتها

على إنتاج نباتات من خمسة هجن للذرة الثامية وهم (جين فردى سينجينتا، هجين ثلاتى ع צr، هجين فردى P344 بيونيير، هجين فردى 30N11 بيونيير، هجين ثلاثى (بر)، وذلك بإستخدام تكنيك زراعة الأجنه غير الناضجة. أظهر تحليل التباين أن جميع الصفات المقاسه تحت ظروف النمو فى المعمل (القدرة على إعطاء كالس، وزن الكالس، الكالس المكون لأجنه خضرية) تأثرت معنويا نتيجة للإختلافات الموجوده بين كل من هجن الذرة الثامية المستخدمة والبيئات الغذائية والتفاعل بينهما. أظهر تحليل 